Cashing in for Growth: Corporate Cash Holdings as an Opportunity for Investment in Japan 


\section{Cashing in for Growth: Corporate Cash Holdings as an Opportunity for Investment in Japan}

Galen Sher 
IMF Working Paper

Asia and Pacific Department

\title{
Cashing in for Growth: Corporate Cash Holdings as an Opportunity for Investment and Growth in Japan
}

Prepared by Galen Sher ${ }^{1}$

Authorized for distribution by Stephan Danninger

December 2014

\section{This Working Paper should not be reported as representing the views of the IMF.} The views expressed in this Working Paper are those of the author(s) and do not necessarily represent those of the IMF or IMF policy. Working Papers describe research in progress by the author(s) and are published to elicit comments and to further debate.

\begin{abstract}
Over the last two decades, cash holdings in nonfinancial firms around the world have increased. This phenomenon is particularly concerning in Japan, where the success of Abenomics depends on a transition from stimulus-driven to self-sustaining growth based on private consumption and investment. This paper finds that Japanese nonfinancial firms have accumulated cash at the expense of investment and dividends, hampering this transition. The evidence suggests that cash accumulation is due to financial imperfections combined with rising corporate profitability and uncertainty, while corporate governance plays only a limited role. These firms have cash holdings available for investment of about 5 percent of GDP. Policy options for encouraging the use of these cash holdings include improving firms' access to market-based financing and discouraging CEO duality.
\end{abstract}

JEL Classification Numbers: E22, E61, G34, G35

Keywords: Japan, Abenomics, cash holdings, investment, growth, transaction cost, precautionary demand, agency cost, corporate governance, CEO duality

Author's E-Mail Address: galen.sher@economics.ox.ac.uk

\footnotetext{
${ }^{1}$ I would like to thank Shi Piao for providing the data and for excellent research assistance. I would also like to thank, without implicating, Adrian Alter, Dennis Botman, Stephan Danninger, Joong Shik Kang, Malhar Nabar, Jerald Schiff and seminar participants in the Asia and Pacific Department for many helpful suggestions.
} 


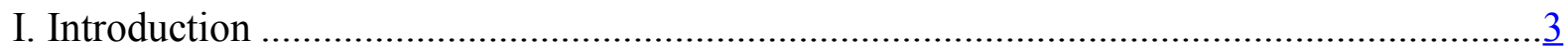

II. Literature on the Determinants of Firm Cash Holdings ..............................................

III. Data and Method ...................................................................................................

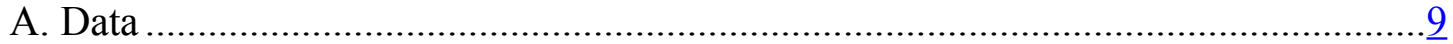

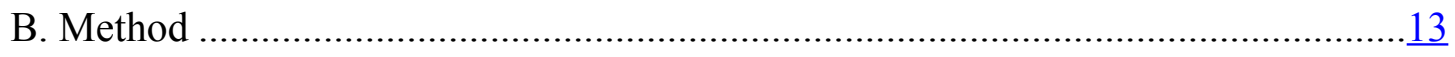

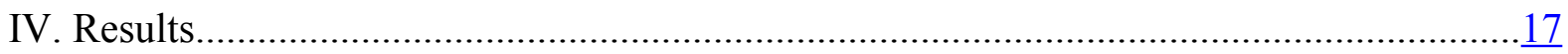

A. Determinants of Cash Holdings ............................................................... 17

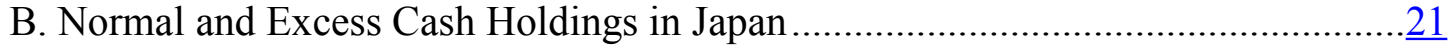

C. Consequences of High and Rising Cash Holdings in Japan................................25

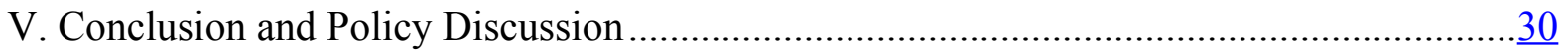




\section{INTRODUCTION}

Over the last two decades, nonfinancial firms around the world have accumulated large holdings of cash assets. ${ }^{2}$ These cash holdings are so large that Bates et al. (2009) find that the average US nonfinancial firm in 2006 could repay all of its debt with cash, and I find the same result for the median Japanese firm in 2013. Japanese nonfinancial firms held cash assets in 2013 of about 50 percent of nominal GDP or 250 percent of aggregate investment. ${ }^{3}$

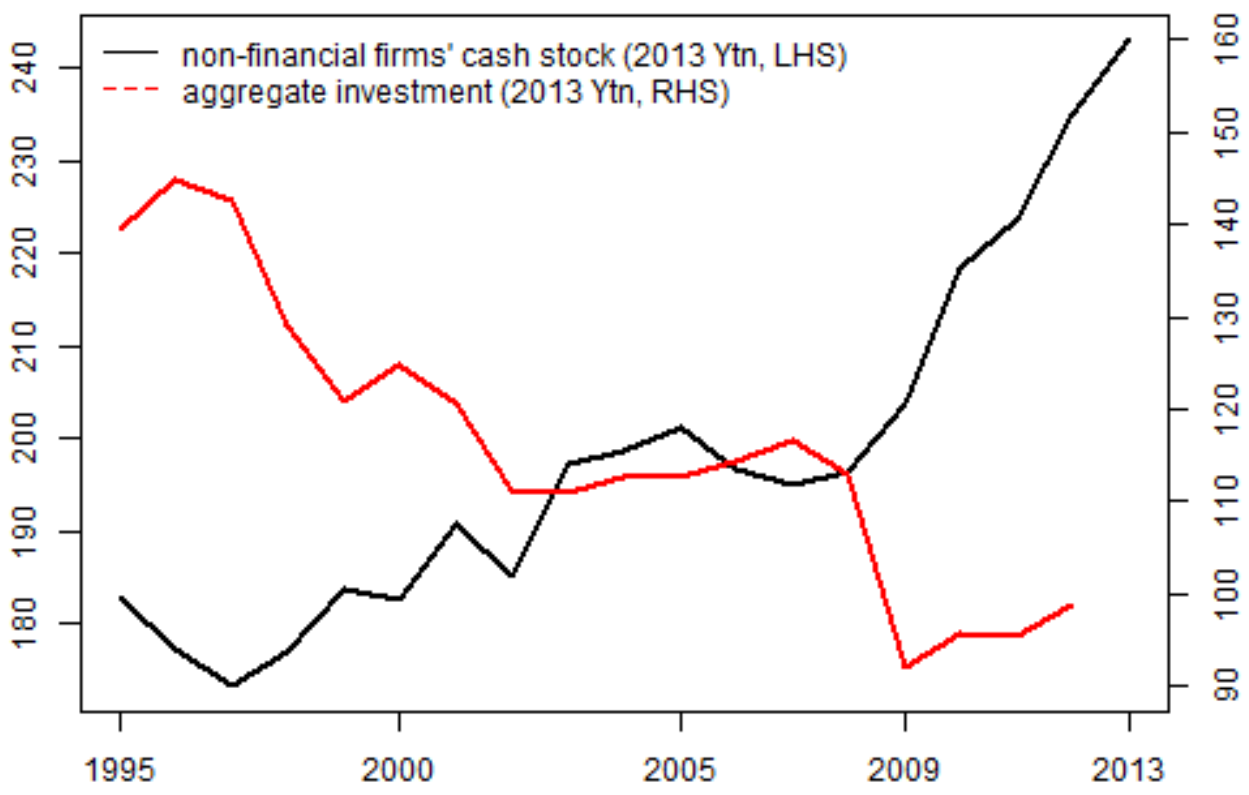

Figure 1. Nonfinancial firms' real holdings of cash assets and real aggregate investment in Japan (Source: National Accounts, Bank of Japan).

The Japanese context is particularly interesting because it is the world's fourth largest economy and its experience with secular near-zero interest rates serves as a reference point for some advanced economies. ${ }^{4}$ Furthermore, Japan has emerged from an extended period of deflation in which inflation-adjusted returns on cash were in fact positive. The bold government policies launched in 2013 have reached a critical juncture where continued growth requires private investment and consumption to take over from fiscal and monetary

\footnotetext{
${ }^{2}$ In this paper I define cash to be money available for use in normal company operations, consistent with the definition of field 02003 in the Worldscope database. Cash in this paper therefore follows a narrow definition that excludes short-term marketable securities.

${ }^{3}$ In 1995 these figures were about 40 percent and 130 percent respectively. (Source: Flow of Funds, Bank of Japan.)

${ }^{4}$ According to the April 2014 edition of the International Monetary Fund's World Economic Outlook database, the countries with the largest gross domestic product by purchasing power parity in 2013 were: the US $(\$ 16.8 \mathrm{tn})$, China $(\$ 13.4 \mathrm{tn})$, India (\$5.1tn) and Japan $(\$ 4.7 \mathrm{tn})$.
} 
stimuli (IMF, 2014). In this context, Figure 1 shows that real aggregate investment has been declining since 1995 while cash holdings in nonfinancial firms have been rising.

It is not surprising therefore that observers have pointed to large cash holdings as a potential obstacle to the success of Abenomics, by hampering growth in wages, investment, and dividend payments. Cash holdings are large in Japan relative to other advanced countries and relative to peer countries. Figure 2 shows that the median firm's average cash-to-asset ratio in Japan is four percentage points higher than in the US. In Asia, the median firm's cash-toasset ratio in Japan is smaller only than China, where financing constraints are thought to be more severe.

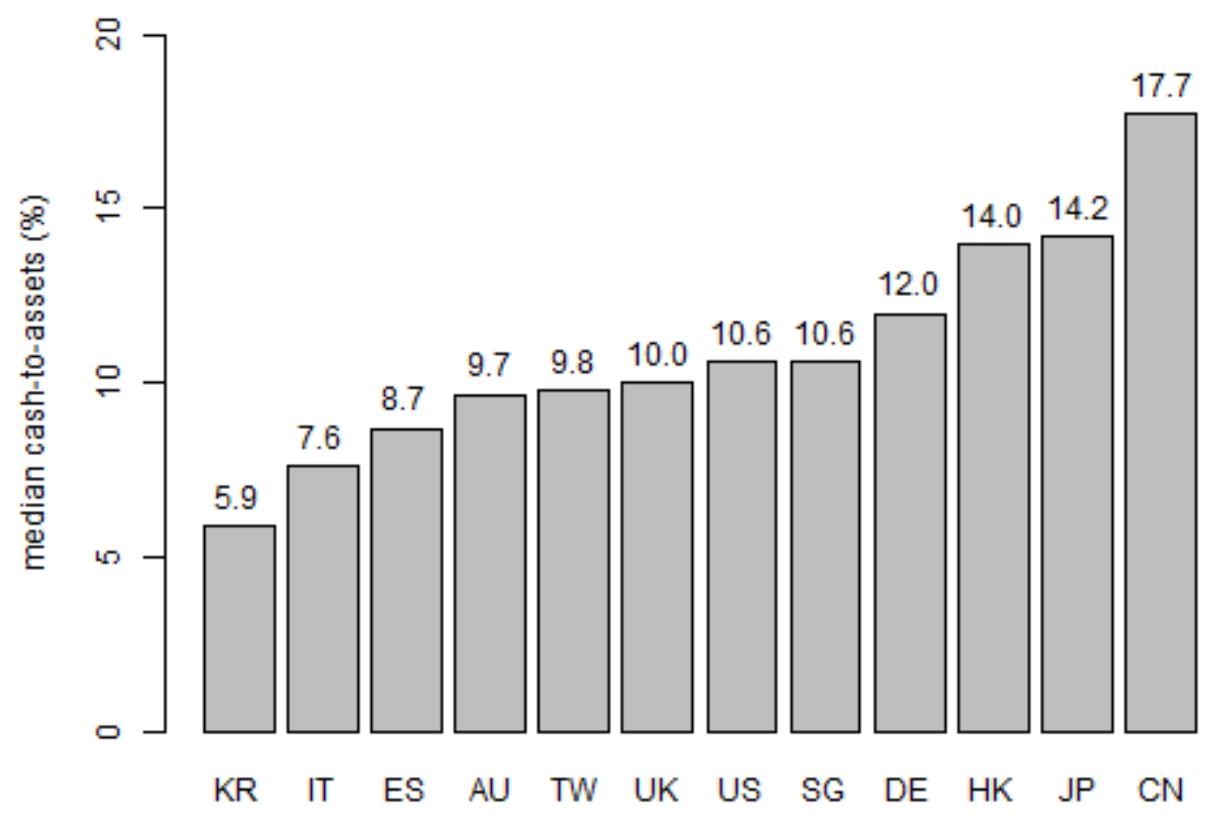

Figure 2. Nonfinancial firms' cash-to-asset ratios across selected countries. Each bar is calculated as the median across firms within that country of the average across years 201012 of the cash-to-asset ratios in that country. Financial firms are excluded based on their Industry Classification Benchmark code (Source: Worldscope).

Figure 3 shows that the median nonfinancial firm's allocation of assets to cash has been growing quicker in Japan than in the US. In the region, the only other country with faster growth of the median firm's allocation of assets to cash has been Taiwan, which is growing from a low base ( 3 percent in 2000). Figure 3 also shows that median cash-to-asset ratios have been high in Japan relative to other advanced Asian economies even as far back as 2000 . 
Nonfinancial firms' cash holdings relative to debt have also grown dramatically in the past decade, as shown in Figure 4. ${ }^{5}$ The median Japanese nonfinancial firm's ratio of cash to debt was 104 percent in 2013, meaning that more than half of Japanese nonfinancial firms could repay all their interest-bearing borrowings with cash. In this sense, the real sector in Japan has become a net lender at a time of negative real interest rates. This stylized fact also casts doubt on the view that these corporate savings are being put to productive use indirectly through the financial intermediation system.

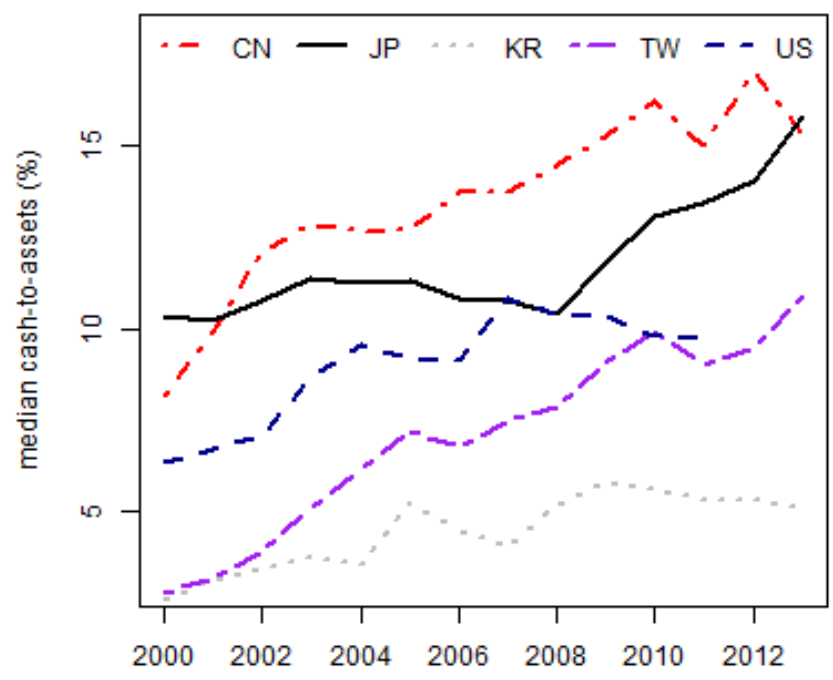

Figure 3. Median nonfinancial firm's cash-toasset ratio in each country-year. Financial firms are excluded based on their Industry Classification Benchmark (Source: Worldscope).

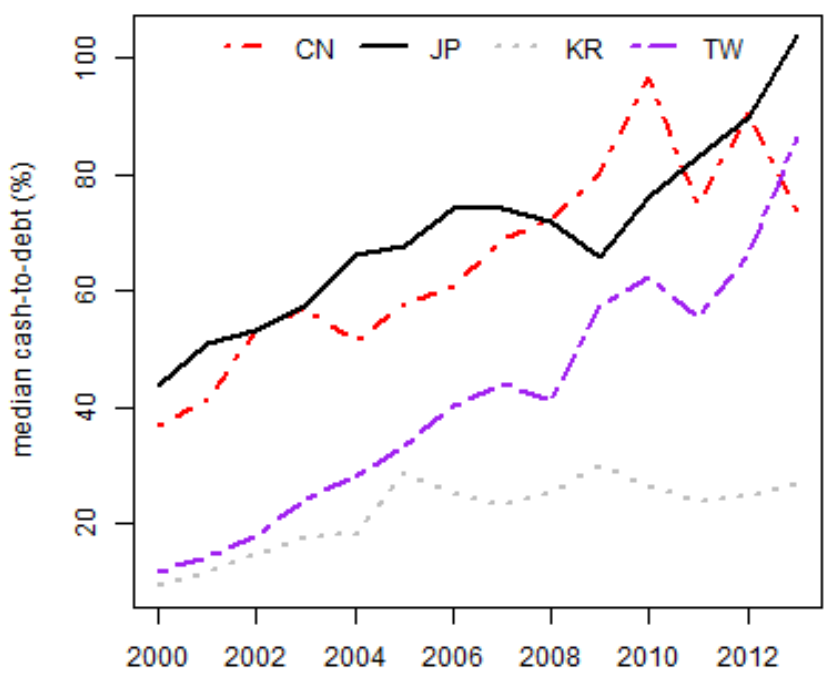

Figure 4. Median nonfinancial firm's cash-todebt ratio in each country-year. Financial firms are excluded based on their Industry Classification Benchmark (Source: Worldscope).

There are four main reasons why firms may choose to accumulate cash. First, there may be transaction costs associated with selling assets or raising external finance to fund a firm's running expenses. A firm therefore finds it cheaper to hold some cash for running expenses than to sell assets or raise finance. Second, the firm's regular cash flow position is subject to some uncertainty, so the higher the risk of low cash inflow or high cash outflow, the more cash a firm would find it prudent to hold. Cash therefore acts as a precautionary buffer to insure the firm against bad states of the world. A third reason that firms hold cash is if there are agency problems like incomplete contracting or asymmetric information that allow management to pursue risk-averse or empire-building strategies at the expense of shareholders. Finally, multinational firms may accumulate cash in foreign subsidiaries to avoid the repatriation tax expense they would incur if they were to repatriate the profits earned in foreign jurisdictions.

\footnotetext{
${ }^{5}$ I consider 'debt' to be interest-bearing contractual financing agreements, as defined by Worldscope.
} 
In this paper I show that the transaction cost and precautionary demand theories can sensibly explain about 80 percent of the variation in cash holdings between Japanese firms and over time. I find limited evidence for the agency cost theory, possibly because of limited data. The transaction cost and precautionary demand theories for corporate cash holdings can explain almost all of the growth in cash-to-asset ratios between 1999 and 2011 in terms of costs of adjusting cash holdings, high operating cash inflows and rising cash flow uncertainty. However, between 2011 and 2013 the transaction cost and precautionary demand theories predicted a fall in the median firm's cash-to-asset ratios, which have instead risen over time. The amount of this 'excess' cash in Japanese nonfinancial firms stands at about 2.5 percent of assets, or 5 percent of GDP, in 2013.

In this paper I also show that high and rising cash holdings leads to lower investment and dividend payments at the firm level, even after controlling for factors thought to explain firm investment and dividend declarations. Policies that divert some of Japan's excess corporate cash savings could therefore be expected to provide the boost to private investment that Japan needs for growth.

In Section II below, I review the theory explaining why firms hold cash and the evidence for and against these theories in the existing empirical literature. Section III discusses the data on Japanese nonfinancial firms and the methods that I use to investigate the causes and consequences of their accumulation of cash in the past decade. I present the results of my analyses in Section IV and discuss conclusions for policy in Section V.

\section{Literature ON THE Determinants OF Firm CASH HoldingS}

The theory of the demand for money by firms dates back to Keynes (1936). He postulated a transaction cost and a precautionary motive for holding cash that have since been formalized. The agency theory that describes how the firm owner's motives for holding cash differ from the firm manager's motives is credited to Jensen (1986). These theories explain why a firm, as an organization of rational people, would choose to hold cash. According to these theories, the cash holding of a firm is the result of the careful cost-benefit analyses of all stakeholders in the firm. However, a firm may also accumulate cash unintentionally, so that the firm's ultimate cash holding is the unplanned result of recent cash inflows and outflows.

Implicit in the above theories of optimal cash holdings is that there is an opportunity cost of allocating assets to cash, which prevents the firm from allocating all of its assets to cash. This opportunity cost could be the foregone earnings on riskier, more productive projects, or the financing cost associated with holding cash rather than paying it to debtholders, shareholders or employees.

Despite the above costs of holding cash, a firm may choose to hold cash for the following four detailed reasons: 
1. The transaction cost motive: a firm benefits from holding some of its assets as cash because it saves on transaction costs, which include (i) the cost of raising external finance when needed and (ii) the cost of liquidating assets when needed. Frictions giving rise to costs associated with raising external finance are brokerage costs (Miller and Orr, 1966) and asymmetric information (Myers and Majluf, 1984). These transaction costs may be fixed or variable, and the higher they are the more of the firm's assets it allocates to cash. To the extent that these transaction costs are fixed, larger firms face economies of scale and hence hold less cash (Bates et al. 2009). The firm needs liquidity in the form of cash or working capital to meet its running expenses that exceed or precede its regular income. Therefore, in the short run we might expect running expenses and cash holdings to be substitutes, while in the long run we would expect them to be positively associated. The transaction cost motive also predicts that more financially constrained firms, which face higher costs of raising external finance, should save more of their cash inflow as cash assets (Almeida et al., 2004).

2. Precautionary demand motive: a firm benefits from holding some of its assets as cash to self-insure against the risk of liquidity shortfalls. Liquidity shortfalls could arise through sudden investment opportunities or contractions in the supply of available financing to the firm. Implicit in this theory is the idea that the firm is risk averse, so that it seeks a stock of cash that is higher than its average cash flow requirements. The higher the uncertainty of the firm's liquidity position and the higher the firm's level of risk aversion, the more of the firm's assets it will allocate to cash. Han and Qiu (2007) show that this risk aversion can be explained by the inter-temporal investment trade-off arising in a model of a firm that maximizes shareholder wealth under financing constraints.

3. Agency cost motive: management benefits from allocating more of the firm's assets to cash than the shareholder wealth-maximizing level because (i) management is typically more risk averse than shareholders, (ii) management seeks financing for future discretionary projects for which raising external finance would be expensive, and (iii) management wants to increase the size of the firm's assets by holding on to firm profits rather than paying them out even when no profitable investment opportunities exist. Management may be more risk averse than shareholders if it has a nondiversifiable pecuniary or reputational interest in the firm. From management's point of view, cash is not negative debt, because management can choose to invest cash even when it could not raise external finance. If management is perceived to be holding cash purely for its own objectives, a dollar of assets allocated to cash may be valued by shareholders at less than a dollar (Opler et al. 1999).

4. Taxation motive: a multinational firm benefits from allocating foreign assets to cash if it would incur an onerous tax expense by repatriating foreign earnings and if it cannot find more profitable investment opportunities abroad (Foley et al., 2007). 
When repatriating profits from a country with lower corporate income tax, a liability is often incurred on the excess of the home corporate income tax rate over the foreign corporate income tax rate.

The empirical evidence in the literature supports the above theories. Mulligan (1997) studies the money demand function for listed US firms using data on 12,000 such firms between 1961 and 1992. The author finds that there are economies of scale in the transaction cost motive for holding cash, or equivalently that larger firms choose to hold less cash because they are less financing constrained. Opler, Pinkowitz, Stulz and Williamson (1999) study the empirical determinants and consequences of the share of assets allocated to cash by 3,600 listed US nonfinancial firms between 1952 and 1994. They find that smaller firms allocate a greater share of assets to cash, consistent with the existence of economies of scale in liquid assets. They also find that firms with more investment and R\&D expenditure allocate a greater share of assets to cash, consistent with R\&D intensive sectors requiring more cash for acquisition activity. They find that firms with more volatile cash flows allocate a greater share of assets to cash, consistent with a precautionary demand for liquid assets. Dittmar, Mahrt-Smith and Servaes (2003) use an international cross-section on 11,000 firms from 45 countries and find that measures of shareholder rights across countries are negatively associated with firms' allocations of assets to cash after controlling for the above effects.

Rajan and Zingales (1995) use panel data on 8,000 listed nonfinancial firms in G7 countries, including 514 Japanese firms, obtained from the Global Vantage database. They show that in 1991, the average Japanese firm allocated 18.4 percent of its assets to cash, with the next highest in the G7 being the UK at 11.4 percent. Pinkowitz and Williamson (2001) use panel data for 1971-1994 on about 7,000 listed nonfinancial firms, including about 1,600 Japanese firms, from the PACAP database and find that the average ratio of cash to total assets across all Japanese firm-years between 1974 and 1995 is 15.6 percent. ${ }^{6}$ They find that Japanese firms with access to the capital markets, in the sense of having ever issued convertible debt, and Japanese firms with a higher ratio of bank debt to total debt hold lower cash-to-asset ratios than other firms after controlling for other variables thought to explain the cash-to-asset ratio.

Naoki (2012) studies panel data on 2,200 listed Japanese firms between 1980 and 2010 from the Development Bank of Japan Databank. The author finds that the median firm's cash-toasset ratio fell from 14 percent in 1988 to 8 percent in 2003 and then increased to 10 percent in 2010. Cash flow volatility peaks after the Asian financial crisis of 1997 and after the global financial crisis of 2008. The main empirical determinant of firms' cash-to-asset ratios is the volatility of cash flow. The author finds that larger cash-to-asset ratios are associated with higher returns on assets and higher market-to-book ratios, so that listed Japanese firms

\footnotetext{
${ }^{6}$ Specifically, Pinkowitz and Williamson (2001) find that the average ratio of cash to total assets minus cash is 18.5 percent. If cash divided by total assets minus cash is 18.5 percent, then cash divided by total assets is $1 /(1+1 / 0.185)=15.6$ percent.
} 
allocating more resources to cash tend to be more profitable and tend to have higher stock market valuations than other firms.

Aoyagi and Ganelli (2014) study yearly panel data on 3,412 nonfinancial Japanese firms between 2000 and 2013 and find that better corporate governance, measured by an index which summarizes disclosure of governance data, is associated with lower ratios of cash to market capitalization. Based on these results, the authors calculate that improving a Japanese firm's corporate governance score from the Japanese average of 39 to the G7 average of 49 could reduce the cash-to-market capitalization ratio from an average of 45 percent to about 42 percent. The authors argue that the effect could be stronger if corporate governance is improved beyond the $\mathrm{G} 7$ average (up to a 23 percentage point reduction in the ratio) and if second-round effects of governance reforms are taken into account.

Ivanova and Raei (2014) study German nonfinancial firm cash holdings in the context of panel data on 24,000 firms from 8 advanced economies (G7 countries plus the Netherlands) between 1991 and 2011. The authors find that Japanese nonfinancial firms have the highest average cash-to-asset ratios in 1998 (16 percent) and 2011 (20 percent) of the countries in their sample, and they find that median cash-to-asset ratios in most countries have been increasing over the past one to two decades.

\section{DAta ANd Method}

\section{A. Data}

To test the above theories, I use a panel dataset of balance sheet and income statement variables of all 4,037 nonfinancial Japanese firms between 1995 and 2013 provided by Thomson Reuters Worldscope. ${ }^{7}$ Following Opler et al. (1999) and Bates et al. (2009), I consider the following explanatory variables for cash holdings, because their explanatory power can be rationalized in terms of the transaction cost and precautionary demand theories:

- $\quad$ Cash flow from operations: The propensity to save operating cash flow is a measure of financing constraints (Almeida et al, 2004). This variable therefore tests both the transaction cost and precautionary demand motives for holding cash, which are affected by the degree to which a firm is financing constrained.

- $\quad$ Cash flow volatility: A positive relationship between cash holdings and cash flow volatility would reflect that firms with riskier cash flow choose to hold more cash, which would provide evidence for the precautionary demand motive. On the other hand, a negative relationship would mean that firms experiencing riskier cash flow

\footnotetext{
${ }^{7}$ The Worldscope database provides balance sheet and income statement information for the consolidated firm to the greatest extent possible.
} 
end up with less cash as a result. A negative relationship would therefore provide some evidence against the view of firms as active optimizing agents.

- Capital expenditure: Capital expenditure is an important control variable for measuring the effect of other variables on cash holdings, but its relationship with cash holdings could be positive or negative, and could reflect active or passive firm behavior. A negative relationship between cash holdings and capital expenditure could reflect the fact that investment improves collateral and borrowing capacity, reducing the cost of raising external finance when needed, which is consistent with both the transaction cost and precautionary demand motives. On the other hand, if capital expenditure measures the desired level of investment, then a positive relationship between cash holdings and capital expenditure would reflect financing constraints causing firms to build up cash reserves to finance their desired investment. Positive or negative associations between cash holdings and capital expenditure are also consistent with the view of cash as the unplanned outcome of shocks to the firm. In the short run, changes in capital expenditure must be financed to some extent by changes in the cash stock when averaging over many firms and points in time, giving rise to a negative relationship. In the long run however, a consistently high level of capital expenditure requires a high cash stock to sustain it due to timing differences between income and expenditure, which would reflect a positive relationship.

- Total assets: A negative relationship between cash holdings and total assets would be consistent with economies of scale in the costs of raising finance or selling assets when needed, which would support both the transaction cost and precautionary demand theories.

- International assets: Firms with international operations may be liable for repatriation tax on foreign profits. In addition, these firms could use a higher level of cash to insure themselves against exchange rate movements. By holding cash in multiple jurisdictions, a firm can avoid transferring cash between them when exchange rates are temporarily unfavorable. A positive relationship between the cash holdings and the proportion of international assets in total assets would reflect such a motivation, which is consistent with the precautionary demand theory. A Japanese manufacturer with productive facilities in low-cost developing countries where financing constraints are more severe would also lower its transaction costs by holding more cash to finance its overseas running expenses. A negative relationship between a firm's cash holdings and international assets would reflect that a firm purchases international assets out of cash holdings.

- $\quad$ Market-to-book ratio: A positive relationship between cash holdings and the marketto-book ratio would indicate that firms with more investment opportunities find cash shortfalls more costly, supporting both the transaction cost and precautionary demand motives. A negative relationship would indicate that firms with better corporate 
governance, and therefore higher valuations, are more successful at curbing managers' incentives to exceed the shareholder wealth-maximizing level of cash holdings, which indicates an agency cost motive.

- $\quad$ Leverage: A negative relationship between cash holdings and leverage indicates there is an opportunity cost of holding cash rather than paying it out to debtholders. ${ }^{8}$ However, the level of correlation between investment needs and operating cash flow determines the preference for more cash relative to less debt (Acharya et al., 2007). Firms with a high correlation between investment needs and operating cash flow require less cash and hence less debt, while firms with low correlation between investment needs and operating cash flow require a cash reserve to protect themselves against times where they need to invest while operating cash flows are not available. Hence if all firms are equally financing constrained and vary only by this level of correlation, then we expect a positive association between cash and leverage, because firms are either high correlation (low cash and debt) or low correlation (high cash and debt). This preference is a form of precautionary demand motive for holding cash.

- $\quad$ Dividends: Dividends are a sign of maturity, stability and access to capital markets. High-dividend firms are less financing constrained and therefore experience a lower cost of selling assets / raising finance when needed and they experience less cash flow uncertainty, so they hold less cash. However, a relationship between cash holdings and dividend payments is also consistent with the interpretation of cash as an unplanned outcome, rather than a conscious firm choice. In the short run, dividends are paid out of cash holdings, so increases/decreases in dividends should be reflected in decreases/increases in cash holdings. In the long run, a high level of dividends must be sustained by a high level of liquidity and therefore a high cash stock.

In addition I consider whether the demand outlook can explain the level of cash holdings. The demand outlook data comes from the Business Outlook Survey conducted by the Cabinet Office and the Ministry of Finance. The reported survey measures the proportion of firms reporting a favorable domestic demand two quarters ahead less the proportion of firms reporting an unfavorable domestic demand two quarters ahead. ${ }^{9}$ I use published aggregates indexed jointly by size, sector and calendar year, which I match to my firm-year Worldscope data using total assets, ICB sector and firm financial year. ${ }^{10}$ To the extent that

\footnotetext{
${ }^{8}$ This negative relationship reflects one of the costs of holding cash, as opposed to "transaction cost" or "precautionary demand" motives which are benefits of cash

${ }^{9}$ Between 1995 and 2004, the Business Outlook Survey only asked firms about their expected "business conditions": two quarters ahead, rather than their demand outlook. My definition of demand outlook is therefore different before and after 2004.

${ }^{10}$ The Business Outlook Survey classifies firms by size into three categories: firms with assets less than ¥100m, firms with assets of between $¥ 100 \mathrm{~m}$ and $¥ 1 \mathrm{bn}$, and firms with assets of over $¥ 1 \mathrm{bn}$.
} 
firm financial years end early in the calendar year, the two-quarter-ahead demand outlook would actually measure a demand outlook over anything up to six quarters ahead. A firm's demand outlook at horizons of between two and six quarters could be expected to be strongly correlated.

To test the agency theory of cash holdings, I obtain the following variables from Bloomberg, which I match to Worldscope data by ISIN and year: ${ }^{11}$

- Audit committee meetings, measured as the number of meetings of the board of directors' audit committee during the reporting period. If more audit committee meetings reflect more care exercised by management on behalf of shareholders, then the number of audit committee meetings would measure the degree of alignment of management and shareholder interests.

- $\quad$ Board average age, measured as the average age of members of the board of directors. To the extent that older boards of directors are more risk averse, they might be inclined to hold more cash.

- $\quad$ CEO duality, a dummy variable indicating whether the firm chief executive officer is also chairman of the board of directors. A dual CEO working closely with the board of directors could indicate closer alignment between management and shareholder interests, but a dual CEO exerting influence on the board of directors could limit the accountability of managers and allow them to pursue their own objectives at the expense of shareholders.

- $\quad$ Ethics policy, a dummy variable indicating whether the firm has established ethical guidelines and/or a compliance policy for its nonmanagement employees in the conduct of the firm's business. An established ethics policy could be a measure of accountability between employees and management and/or a sign of management transparency. On the one hand, accountability and transparency indicate closer alignment of manager and shareholder interests, better corporate governance and lower cash. On the other hand, better governance is associated with lower shareholder risk, financing costs, and opportunity costs of holding cash.

- Disclosure score, a proprietary Bloomberg score between 0 and 100 measuring the proportion of data items that Bloomberg is able to obtain about the firm from the firm's public disclosures. Items are weighted according to their importance in the firm's industry. The disclosure score is a measure of transparency. Like the existence of a firm ethics policy, the disclosure score could be associated with lower cash if it indicates better alignment of manager and shareholder interests, or higher cash if it

\footnotetext{
${ }^{11}$ ISIN stands for International Security Identification Number, and uniquely identifies securities trading on exchanges worldwide. I match Bloomberg data to Worldscope data using the ISIN for the company's stock.
} 
indicates lower opportunity costs of holding cash rather than paying that cash out to financiers.

- Independent directors, measured as the proportion (in percent) of members of the board of directors that are external to the firm. Independent directors could be expected to act more impartially than directors who have business dealings with the firm. This impartiality could be an advantage for shareholders if it better aligns manager and shareholder interests, but it could be a disadvantage to shareholders if it is accompanied by complacency that concentrates power with the remaining nonindependent directors.

- $\quad$ Nonexecutive directors, measured as the proportion (in percent) of members of the board of directors that are not part of the firm's executive management team. Nonexecutive directors differ from independent directors in that the former may hold an ownership stake in the firm.

Better corporate governance measures like transparency and accountability could reduce the risks of insolvency, fraud, fines and legal action. Such risk reductions also reduce the cash flow uncertainty of the firm and therefore reduce the need for firms to self-insure through holding cash.

\section{B. Method}

\section{Fixed effect and system GMM regressions for cash holdings and investment}

Let the latent target cash-to-asset ratio for firm $i$ in period $t$ be given by

$y_{i t}^{*}=x^{\prime}{ }_{i t} \delta+\phi_{t}+\epsilon_{i t}, i=1, \ldots, N, t=1, \ldots, T$

where $x_{i t}$ is a $K \times 1$ vector of determinants for firm $i$ in period $t, \phi_{t}$ is a deterministic component describing the contribution of firm-invariant time-specific variables like aggregate interest rates or economic growth to the firm's target cash-to-asset ratio, and $\epsilon_{i t}$ is a noise component with zero mean. Equation (1) could arise as the first order condition in an optimization problem for the level of cash holdings of firm $i$ in period $t$, or it could arise in some heuristic manner if firm $i$ in period $t$ does not necessarily optimize. Equation (1) is a static relationship for firm $i$ in period $t$ in the sense that it does not depend on lagged values of the cash-to-asset ratio. Suppose that firm $i$ in period $t$ rebalances its actual cash-to-asset ratio $y_{i t}$ from one period to the next according to

$y_{i t}-y_{i t-1}=\lambda\left(y_{i t}^{*}-y_{i t-1}\right), i=1, \ldots, N, t=1, \ldots, T$

where $0 \leq \lambda \leq 1$ is the speed of adjustment. When $\lambda=1$ the firm immediately adjusts its cash-to-asset ratio to the target from one period to the next, and when $\lambda=0$ the firm does not adjust its cash-to-asset ratio. For an optimizing firm when $\lambda<1$, the quantity $1-\lambda>0$ 
could therefore be interpreted as the cost of adjusting cash-to-asset ratios from one period to the next, which rationally induces the firm to slow its adjustment of cash-to-asset ratios relative to target. Such costs could include the fixed costs associated with selling illiquid assets or raising external finance to raise cash. For optimizing firms, the cost of adjustment should be increasing in the sampling frequency, so that $\lambda$ should be higher if periods are measured in years than if periods are measured in quarters, for example. For a nonoptimizing firm, the speed of adjustment parameter $\lambda$ can be interpreted as an outcome of the firm's heuristic behavioral rule.

Combining (1) and (2) and re-parametrizing $\alpha=1-\lambda, \lambda \delta=\beta, \theta_{t}=\lambda \phi_{t}$ and $\lambda \epsilon_{i t}=c_{i}+$ $u_{i t}$ gives the data generating process for the cash-to-asset ratio for firm $i$ in period $t$

$y_{i t}=\alpha y_{i t-1}+x_{i t}^{\prime} \beta+\theta_{t}+c_{i}+u_{i t}, i=1, \ldots, N, t=1, \ldots, T$

where $c_{i}$ is a random component that controls for unobserved time-invariant firm-specific variables like the type of firm, the firm's objectives and mission, or the time-invariant component of the firm-specific level of management risk aversion or corporate governance structure. ${ }^{12,13}$ When $\lambda=1$, we have $\alpha=0$ and model (3) is equivalent to model (1) with the target cash-to-asset ratio equal to the actual cash-to-asset ratio.

The parameters in model (3) cannot be consistently estimated by fixed effects regression because the lagged dependent variable $y_{i t-1}$ is correlated with the firm-specific effect $c_{i}$. When $\alpha=0$, these parameters can be consistently estimated by fixed effects, but this consistency relies on the exogeneity assumption $E\left(u_{i s} \mid x_{i 1} \ldots x_{i T}\right)=0$ for all $i$ and $s$, which requires that the correlation between the idiosyncratic error $u_{i t}$ and the explanatory variables $x_{i t}$ be uncorrelated at all leads and lags. In particular, we may be concerned that some of the explanatory variables like capital expenditure might be correlated with past idiosyncratic shocks to the cash-to-asset ratio. The system generalized method of moments (GMM) estimator of Arellano and Bond (1991), Arellano and Bover (1995) and Blundell and Bond (1998) weakens this exogeneity condition to

$E\left(x_{i s} \Delta u_{i t}\right)=0$ for all $i$ and for all $s<t$

while strengthening it by adding the exogeneity condition

$E\left(\Delta x_{i t}\left(c_{i}+u_{i T}\right)\right)=0$ for all $i$ and for all $t$

\footnotetext{
${ }^{12}$ I add control variables for management risk aversion and measurable corporate governance standards, but these concepts are difficult to measure due to their richness and to missing data. To the extent that some elements of risk aversion or corporate governance structure are time-invariant, one can capture these effects through the firm-specific error component $c_{i}$.

${ }^{13}$ Importantly, the evidence here cannot be construed as causal because the dependent and explanatory variables in (3) are jointly determined.
} 
so that we only require that lags of the explanatory variables be uncorrelated with the idiosyncratic error. In other words, we place no restriction on feedback from past shocks to the cash-to-asset ratio on current and future explanatory variables like capital expenditure. The second exogeneity condition requires that the steady state level of the cash-to-asset ratio is not correlated with lagged changes in the explanatory variables, which is plausible in our context.

\section{Tobit and linear probability model regressions for dividends}

I test both whether cash holdings affect the magnitude of a firm's dividend declarations and the likelihood of a firm declaring dividends by estimating two types of regression. To test for the effect of cash on the magnitude of dividends, I estimate the doubly-censored tobit model

$\tilde{y}_{i t}=\min \left(\max \left(0, x^{\prime}{ }_{i t} \beta+\theta_{t}+u_{i t}\right), 1\right), i=1, \ldots, N, t=1, \ldots, T$

where $\tilde{y}_{i t}$ is the dividend payout ratio for firm $i$ in year $t$ when it lies between 0 and 100 percent, $x^{\prime}{ }_{i t}$ is a $1 \times K$ vector of the above explanatory variables including industryspecific dummy variables, $\theta_{t}$ is a time-specific component capturing the effects of all measurable macroeconomic fluctuations, $\beta$ is a $K \times 1$ vector of coefficients and $u_{i t}$ is an idiosyncratic shock. ${ }^{14}$ I restrict attention to dividend payout ratios between 0 and 100 percent because these are typical instances where a firm makes a profit and then decides to pay out a proportion of that profit as a dividend. Atypical instances where a loss-making firm declares a dividend or a profit-making firm declares a dividend in excess of its annual profit are more difficult to understand and are beyond the scope of this analysis.

To test for the effect of cash holdings on the likelihood of a firm declaring dividends, I estimate the linear probability model for whether or not the firm declares dividends in a given year following Denis and Osobov (2008):

$\mathbb{I}\left\{y_{i t}>0\right\}=x^{\prime}{ }_{i t} \beta+\theta_{t}+c_{i}+u_{i t}, i=1, \ldots, N, t=1, \ldots, T$

where $\mathbb{I}$ is the indicator function, $y_{i t}$ is the (uncensored) dividend payout ratio for firm $i$ in year $t, \theta_{t}$ is a time-specific component capturing the effects of all macroeconomic fluctuations, $c_{i}$ is a firm-specific fixed effect and $x^{\prime}$ it is a vector of explanatory variables without industry-specific dummy variables. ${ }^{15,16}$

\footnotetext{
${ }^{14}$ Including firm-specific fixed effects in a tobit model yields inconsistent estimation of $\beta$ (Wooldridge, 2010).

${ }^{15}$ The industry-specific dummy variables in equation (2) are redundant in the presence of the firm-specific dummy variables in equation (3).

${ }^{16}$ The dividend payout ratio in each firm — year is defined as the ratio of declared dividends per share, including extra dividends and excluding special dividends, to basic earnings per share.
} 


\section{Measuring corporate risk aversion}

In choosing between a random normally distributed risky return $r_{i t}$ and a risk free return $\bar{r}_{t}$, an investor with preferences described by a constant absolute risk aversion utility function with risk aversion parameter $a$ allocates a proportion

$w_{i t}=\frac{E\left(r_{i t}-\bar{r}_{t}\right)}{a V\left(r_{i t}\right)}$

of her wealth in the risky asset and the remainder $1-w_{i t}$ in the risk free asset, where $E$ denotes the expectation operator and $V$ denotes the variance operator.

By observing the allocation $1-w_{i t}$ of the assets of firm $i$ in year $t$ to cash, the return on which is approximately risk free and observable, and by estimating the mean and variance of the return to firm $i$ in year $t$ of allocating its assets to other, productive assets, one can infer the risk aversion parameter $a$ from equation (4) above. By re-arranging equation (4) to

$$
a=\frac{E\left(r_{i t}-\bar{r}_{t}\right)}{V\left(r_{i t}\right)} / w_{i t}
$$

one obtains the useful interpretation of parameter $a$ as the ratio of the amount that a riskneutral agent would allocate to the risky asset to the amount that the firm actually allocates to the risky asset. If the firm allocates less to the risky asset than the risk neutral agent would, then the firm is risk averse. Conversely, the parameter $a$ can be interpreted simply as the amount that the firm allocates to cash in excess of what the above risk neutral agent would allocate to cash.

I estimate $E\left(r_{i t}\right)$ and $V\left(r_{i t}\right)$ using the mean and variance of returns on assets for all firmyears in the same first-digit ICB industry as firm $i$ between years $t-2$ and $t+2$ inclusive. The use of future-dated returns allows for forward-looking expectations and pooling returns across firms within an industry limits the means and variances of returns to reasonable values. I estimate the return on the risk free asset $\bar{r}_{t}$ by principal interest rates on ordinary deposits and savings at banks in year $t$ published by the Bank of Japan, which are common to all firms in any given year.

Nonfinancial firms are not utility-maximizing investors and to the extent that they choose their asset allocation, this decision reflects more considerations than simply the risk-adjusted expected return on productive assets in excess of the return on cash. Nevertheless observers often comment that Japanese managers are more risk averse than their US counterparts, so even a highly stylized measure of risk aversion could help us test whether preferences can explain some of the variation in cash holdings in Japan. 


\section{Results}

\section{A. Determinants of Cash Holdings}

I present fixed effect and system generalized method of moments regression estimation results in Table 1. The baseline specifications following Opler et al. (1999) and Bates et al. (2009) are in columns (1) and (2). My contribution to the baseline specification is (i) to add a lagged dependent variable to capture the persistence of cash-to-asset ratios over time, and (ii) to add a control variable for survey expectations of the demand outlook two quarters ahead, which I match to firm-years using industry and size characteristics.

The signs and magnitudes of the statistically significant coefficients in columns (1) and (2) agree with those found in the empirical literature and can be rationalized in terms of the above explanations. In this sense, they generally support the transaction cost and precautionary demand theories of cash holdings. The statistically significant coefficients also agree between fixed effect and system GMM estimations. The preferred baseline specification is the system GMM specification with a lagged dependent variable in column (2) because the exogeneity assumptions required for consistent estimation of the coefficients in the latter model are more plausible.

The coefficient on the lagged dependent variable is positive, less than unity and statistically significant, indicating stationarity and persistence in cash-to-asset ratios over time. The persistence could reflect the costs to the firm of adjusting its cash holdings from one year to the next. Alternatively the firm's cash holdings could be viewed as an unplanned outcome of cash inflows and outflows, in which cash the persistence in cash-to-asset ratios reflects the degree to which Japanese nonfinancial firms do not actively manage their cash holdings.

The coefficient on operating cash flow is positive, reflecting the propensity of firms to save positive cash flow due to financing constraints. The coefficient on rolling standard deviation of cash flow is positive, so that firms with riskier cash flows tend to hold more cash to selfinsure against cash shortfalls. I obtain a negative coefficient on capital expenditures, which could reflect the extent to which firms choose to finance their investment spending out of cash holdings, due to financing constraints or asymmetric information about the nature of investment projects between management and financiers. Bates et al. (2009) explain this negative coefficient as the reduced financing constraints associated with the increased collateral that follows increased investment spending. Another interpretation is that cash is not the outcome of a conscious decision by the firm. In this case, managers invest when they have cash on hand, and the effect of investing is to drawn down on cash holdings. The coefficient on the firm's expectations for future demand is significantly negative, consistent with the interpretation that firms deploy cash in response to improving demand conditions.

I add a control variable for risk aversion in specifications (3) and (4) of Table 1, estimated using fixed effects and system GMM respectively. I describe the construction of this variable above. The risk aversion variable is self-referential in that its calculation depends on the very 
cash-to-asset ratio that it is purporting to explain. The rolling mean and standard deviations of returns that are used in the calculation exhibit limited time variation and are hence difficult to distinguish from the firm-specific fixed effects. Nevertheless there is some evidence for a positive coefficient on this variable, but only in the fixed effect specification. A positive coefficient could reflect that even when holding the riskiness of cash flows constant, firms with more risk averse managers tend to hold higher levels of cash.

Table 1. Fixed effect and system GMM regressions on a firm--year panel of Japanese nonfinancial firms where the dependent variable is the cash-to-asset ratio. Estimations without lagged dependent variables, instruments and Hansen test p-values are fixed effect estimations. Fixed effects estimations are reported with heteroskedasticity-robust standard errors and system GMM estimations are reported with Windmeijer-corrected standard errors, in parentheses. Coefficients or standard errors of zero are only zero to two decimal places; such coefficients are not economically significant. All estimations include time-specific fixed effects to control for all macroeconomic fluctuations. In each estimation, the reported $R^{2}$ is calculated as the squared correlation between actual and fitted values of the dependent variable. 


\begin{tabular}{|c|c|c|c|c|}
\hline & \multicolumn{2}{|c|}{ baseline } & \multicolumn{2}{|c|}{ controlling for risk aversion } \\
\hline & $\begin{array}{c}\text { (1) } \\
\text { cash-to-assets } \\
\text { ( percent) }\end{array}$ & $\begin{array}{c}(2) \\
\text { cash-to-assets } \\
\text { ( percent) }\end{array}$ & $\begin{array}{c}\text { (3) } \\
\text { cash-to-assets } \\
\text { ( percent) }\end{array}$ & $\begin{array}{c}\text { (4) } \\
\text { cash-to-assets } \\
\text { ( percent) }\end{array}$ \\
\hline \multirow[t]{2}{*}{ cash-to-assets $($ percent $)=\mathrm{L}$, } & & $0.74 * * *$ & & $0.71 * * *$ \\
\hline & & $(0.03)$ & & $(0.03)$ \\
\hline \multirow[t]{2}{*}{ cash flow to assets } & $5.16^{* *}$ & $10.46 * * *$ & $4.12 * *$ & $11.04 * * *$ \\
\hline & $(2.01)$ & $(3.72)$ & $(2.06)$ & (3.93) \\
\hline \multirow[t]{2}{*}{ firm cash flow $5 y r$ vol. to assets } & $0.02 * * *$ & $0.03 * * *$ & $0.01 * *$ & $0.03^{* * *}$ \\
\hline & $(0.01)$ & $(0.01)$ & $(0.01)$ & $(0.01)$ \\
\hline \multirow[t]{2}{*}{ capital exp. ( percent assets) } & $-0.23 * * *$ & $-0.20 * * *$ & $-0.22 * * *$ & $-0.27^{* * *}$ \\
\hline & $(0.04)$ & $(0.06)$ & $(0.04)$ & $(0.05)$ \\
\hline \multirow[t]{2}{*}{ operating exp. ( percent assets) } & $-0.03 * * *$ & -0.01 & $-0.03 * * *$ & -0.00 \\
\hline & $(0.01)$ & $(0.00)$ & $(0.01)$ & $(0.00)$ \\
\hline \multirow[t]{2}{*}{ R\&D exp. ( percent assets) } & -0.09 & 0.11 & -0.01 & $0.25 * *$ \\
\hline & $(0.19)$ & $(0.11)$ & $(0.12)$ & $(0.10)$ \\
\hline \multirow[t]{2}{*}{ borrowing rate ( percent) } & 0.00 & -0.00 & 0.00 & 0.00 \\
\hline & $(0.00)$ & $(0.00)$ & $(0.00)$ & $(0.00)$ \\
\hline \multirow[t]{2}{*}{ total assets (log) } & $-1.95^{* * *}$ & -0.09 & $-1.57^{* *}$ & -0.10 \\
\hline & $(0.66)$ & $(0.11)$ & $(0.65)$ & $(0.12)$ \\
\hline \multirow[t]{2}{*}{ Leverage } & 0.00 & 0.00 & 0.00 & 0.00 \\
\hline & $(0.00)$ & $(0.00)$ & $(0.00)$ & $(0.00)$ \\
\hline \multirow[t]{2}{*}{ dividends ( percent total assets) } & 0.47 & 0.22 & 0.26 & 0.44 \\
\hline & $(0.29)$ & $(0.29)$ & $(0.27)$ & $(0.33)$ \\
\hline \multirow[t]{2}{*}{ market-to-book ratio } & $-0.05 * *$ & -0.03 & -0.03 & -0.02 \\
\hline & $(0.02)$ & $(0.03)$ & $(0.02)$ & $(0.03)$ \\
\hline \multirow[t]{2}{*}{ international assets ( percent) } & $-4.48 * * *$ & 1.08 & $-3.63 * * *$ & $1.84^{* *}$ \\
\hline & $(0.80)$ & $(0.73)$ & $(0.86)$ & $(0.75)$ \\
\hline \multirow[t]{2}{*}{ size-sector demand outlook } & -0.01 & $-0.07 * * *$ & $-0.05 * * *$ & $-0.07 * * *$ \\
\hline & $(0.01)$ & $(0.01)$ & $(0.01)$ & $(0.01)$ \\
\hline \multirow[t]{2}{*}{ risk aversion } & & & $0.04 * * *$ & 0.00 \\
\hline & & & $(0.01)$ & $(0.02)$ \\
\hline Observations & 14,346 & 14,346 & 11,574 & 11,574 \\
\hline Number of firms & 1,755 & 1,755 & 1,403 & 1,403 \\
\hline $\mathrm{R}^{2}$ & 0.781 & 0.786 & 0.794 & 0.769 \\
\hline Number of instruments & & 1328 & & 1145 \\
\hline Hansen test $p$-value & & 0.385 & & 0.111 \\
\hline
\end{tabular}

Robust standard errors in parentheses

*** $p<0.01,{ }^{* *} p<0.05, * p<0.1$

Table 2 presents the estimation results for the baseline system GMM specification with explanatory variables for corporate governance obtained from Bloomberg. I consider seven measures of corporate governance. Data limitations seriously restrict the available sample for estimation, so the standard errors on coefficients are relatively large. In specification (1) with a full set of governance variables, only the number of audit committee meetings is even marginally statistically significant. This coefficient has a positive sign, indicating that for the average firm in the sample, one additional audit committee meeting per year tends to results in about a 0.3 percent increase in the cash-to-asset ratio, which may be a sign that Japanese 
nonfinancial firms engage in too many audit committee meetings on average. However, the Hansen test $p$-value in specification (1) is less than 10 percent, indicating some misspecification.

Specifications (2) to (8) estimate the baseline system GMM specification with only one corporate governance variable included in each case. None of the Hansen tests reject the over-identifying exogeneity conditions. ${ }^{17}$ Evidence in specification (4) suggests that having the CEO act in a dual capacity also as the chairman of the board tends to increase the firm's cash by 1.04 percent of its assets, which is consistent with the interpretation of dual CEOs exerting control over the board of directors at the expense of shareholders.

In specification (7), increasing the proportion of independent directors on the executive board by 1 percent tends to result in a 0.05 percent increase in the share of the firm's assets allocated to cash. This finding suggests that the inexperience or complacency of independent directors in Japanese nonfinancial firms outweighs their impartiality and allows mangers to accumulate cash at the expense of shareholders. This positive relationship between cash holdings and independent director representation suggests we should be skeptical of the view that current reforms in Japan to improve the share of independent director representation on executive boards could be expected to reduce the shares of nonfinancial firms that are allocated to cash.

Table 2. System GMM regressions for cash-to-asset ratios on Japanese nonfinancial firm-year panel data. All estimations include the control variables from the baseline specification in Table 1 model (2) above, including a lagged dependent variable and firm- and timespecific fixed effects, coefficients on which are not reported to save space. Standard errors are reported in parentheses and allow for the Windmeijer correction. In each estimation, the reported $R^{2}$ is calculated as the squared correlation between actual and fitted values of the dependent variable.

\footnotetext{
${ }^{17}$ The p-value of the Hansen test in specification (2) of Table 1 is close to 1, indicating there may be a problem of too many instruments in this specification. This observation does not affect my findings.
} 


\begin{tabular}{|c|c|c|c|c|c|c|c|c|}
\hline & $\begin{array}{c}\text { (1) } \\
\text { cash-to- } \\
\text { assets } \\
\text { ( percen } \\
\text { t) }\end{array}$ & $\begin{array}{c}\text { (2) } \\
\text { cash-to- } \\
\text { assets } \\
\text { ( percen } \\
\text { t) } \\
\end{array}$ & $\begin{array}{c}\text { (3) } \\
\text { cash-to- } \\
\text { assets } \\
\text { ( percen } \\
\text { t) } \\
\end{array}$ & $\begin{array}{c}\text { (4) } \\
\text { cash-to- } \\
\text { assets } \\
\text { ( percen } \\
\text { t) }\end{array}$ & $\begin{array}{c}\text { (5) } \\
\text { cash-to- } \\
\text { assets } \\
\text { ( percen } \\
\text { t) }\end{array}$ & $\begin{array}{c}\text { (6) } \\
\text { cash-to- } \\
\text { assets } \\
\text { ( percen } \\
\text { t) } \\
\end{array}$ & $\begin{array}{c}\text { (7) } \\
\text { cash-to- } \\
\text { assets } \\
\text { ( percen } \\
\text { t) } \\
\end{array}$ & $\begin{array}{c}\text { (8) } \\
\text { cash-to- } \\
\text { assets } \\
\text { ( percen } \\
\text { t) }\end{array}$ \\
\hline $\begin{array}{l}\text { audit } \\
\text { committee } \\
\text { meetings }\end{array}$ & $\begin{array}{l}0.30^{*} \\
(0.17)\end{array}$ & $\begin{array}{c}0.05 \\
(0.06)\end{array}$ & & & & & & \\
\hline $\begin{array}{l}\text { board average } \\
\text { age }\end{array}$ & $\begin{array}{c}0.04 \\
(0.14)\end{array}$ & & $\begin{array}{l}-0.06 \\
(0.08)\end{array}$ & & & & & \\
\hline CEO duality & $\begin{array}{c}0.68 \\
(0.63)\end{array}$ & & & $\begin{array}{l}1.04 * * \\
(0.52)\end{array}$ & & & & \\
\hline $\begin{array}{l}\text { ethics policy } \\
\text { disclosure }\end{array}$ & $\begin{array}{c}2.25 \\
(2.80)\end{array}$ & & & & $\begin{array}{l}-2.24 \\
(2.43)\end{array}$ & & & \\
\hline score & $\begin{array}{c}0.07 \\
(0.15)\end{array}$ & & & & & $\begin{array}{c}0.01 \\
(0.02)\end{array}$ & & \\
\hline $\begin{array}{l}\text { independent } \\
\text { directors } \\
\text { ( percent) }\end{array}$ & $\begin{array}{l}-0.01 \\
(0.06)\end{array}$ & & & & & & $\begin{array}{c}0.05 * * \\
(0.02)\end{array}$ & \\
\hline $\begin{array}{l}\text { nonexecutive } \\
\text { directors } \\
\text { ( percent) }\end{array}$ & $\begin{array}{l}-0.02 \\
(0.05)\end{array}$ & & & & & & & $\begin{array}{c}0.02 \\
(0.02)\end{array}$ \\
\hline $\begin{array}{l}\text { Observations } \\
\text { Number of }\end{array}$ & 2,528 & 2,528 & 2,528 & 2,528 & 2,528 & 2,528 & 2,528 & 2,528 \\
\hline firms & 825 & 825 & 825 & 825 & 825 & 825 & 825 & 825 \\
\hline $\begin{array}{l}\mathrm{R}^{2} \\
\text { Number of }\end{array}$ & 0.711 & 0.818 & 0.821 & 0.816 & 0.819 & 0.820 & 0.813 & 0.819 \\
\hline $\begin{array}{l}\text { instruments } \\
\text { Hansen test } p \text { - } \\
\text { value }\end{array}$ & 0.0812 & 0.996 & 0.284 & $\begin{array}{c}491 \\
0.236\end{array}$ & 0.349 & $\begin{array}{r}499 \\
0.325\end{array}$ & $\begin{array}{c}488 \\
0.392\end{array}$ & $\begin{array}{c}494 \\
0.236\end{array}$ \\
\hline
\end{tabular}

\section{B. Normal and Excess Cash Holdings in Japan}

From Table 1 above, the baseline system GMM regression is able to explain close to 80 percent of the variation in cash-to-asset ratios across 1,755 firms and 19 years. This proportion can be interpreted as the variation in Japanese nonfinancial firm cash holdings 
that is explainable by the transaction cost and precautionary demand theories. ${ }^{18}$ In this sense, the fitted values from this baseline estimation can be interpreted as 'normal' levels of cash holdings, while the residuals can similarly be interpreted as 'excess' cash holdings. ${ }^{19}$

Figure 5 presents the evolution of the median actual and baseline fitted cash-to-asset ratio over time for the full sample of 4,037 Japanese nonfinancial firms. The plot suggests that the transaction cost and precautionary demand theories can explain most of the increase in Japanese nonfinancial firm cash-to-asset ratios between 1999 and 2011. Between 2011 and 2013 however, Japanese nonfinancial firms continued to accumulate cash rapidly while their characteristics and past behavior suggest that cash-to-asset ratios should have declined over this period. The main factor contributing to the expected decline in cash-to-asset ratios between 2011 and 2013 is an improving demand outlook.

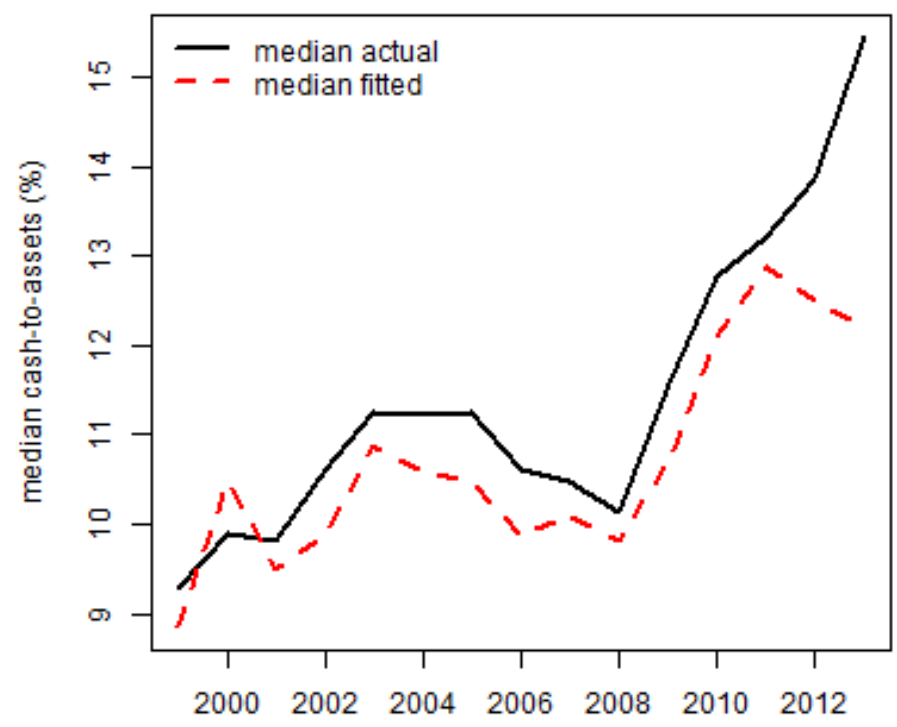

Figure 5. Median across firms in each year of the actual cash-to-asset ratio and fitted cash-toasset ratio according to the baseline system GMM specification.

One can infer the implied target cash-to-asset ratios for firm $i$ in year $t$ using

\footnotetext{
${ }^{18}$ The $\mathrm{R}^{2}$ of 80 percent is calculated as the squared correlation between the fitted cash-to-asset ratios $\hat{y}_{i t}$ and actual cash-to-asset ratios in the regression sample of Table 1 . Time dummy variables therefore contribute to this $\mathrm{R}^{2}$. I measure the sensitivity of the $\mathrm{R}^{2}$ to these time dummy variables by calculating the squared correlation between the actual cash-to-asset ratios and the fitted cash-to-asset ratios excluding time dummies $\hat{y}_{i t}-\hat{\theta}_{t}$. The $\mathrm{R}^{2}$ with the time dummy variables exceeds the $\mathrm{R}^{2}$ without the time dummy variables by 0.08 percent, so that the time dummy variables in this case add very little explanatory power to the model for cash-to-asset ratios.

${ }^{19}$ To the extent that the theory of cash holdings is incomplete, the residuals from the baseline regression can also be interpreted as the component of cash holdings that cannot be explained by existing theory. Incomplete data could also contribute to this inability to explain cash holdings.
} 


$$
\hat{y}_{i t}^{*}=x_{i t}^{\prime} \hat{\delta}+\hat{\phi}_{t}=\frac{1}{1-\hat{\alpha}}\left(x_{i t}^{\prime} \hat{\beta}+\hat{\theta}_{t}\right)
$$

in which case the change in implied target cash-to-asset ratios for firm $i$ between years $s$ and $t$ is

$$
\hat{y}_{i t}^{*}-\hat{y}_{i s}^{*}=\frac{1}{1-\hat{\alpha}}\left[\left(x_{i t}^{\prime}-x_{i s}^{\prime}\right) \hat{\beta}+\hat{\theta}_{t}-\hat{\theta}_{s}\right]
$$

and the average change in target cash-to-asset ratios across all firms $i=1, \ldots, N$ can be written in terms of the average change in explanatory variables as

$$
\sum_{i=1}^{N}\left(\hat{y}_{i t}^{*}-\hat{y}_{i s}^{*}\right)=\frac{1}{1-\hat{\alpha}}\left[\sum_{i=1}^{N}\left(x_{i t}-x_{i s}\right)^{\prime} \hat{\beta}+\hat{\theta}_{t}-\hat{\theta}_{s}\right],
$$

where $x^{\prime}{ }_{i t}$ is the $1 \times K$ vector of explanatory variables for firm $i$ at time $t, \hat{\beta}$ is the $K \times 1$ vector of coefficients estimated according to system GMM in Table 1 model (2) above, and $\hat{\theta}_{t}$ is the estimated time-specific fixed effect at time $t$.

Figure 6 shows a bar plot decomposing this average increase in target cash-to-asset ratios $\hat{y}_{i t}^{*}$ into the average changes in explanatory variables. Of the 2.5 percent increase in average target cash-to-asset ratios between 1999 and 2011, roughly equal proportions of the increase can be explained by each of:

- financially constrained optimizing firms choosing to save their cash inflows, or nonoptimizing firms unintentionally letting their cash reserves accumulate

- financially constrained optimizing firms choosing to hold higher levels of cash due to rising uncertainty in operating cash flow

- nonoptimizing firms cutting back on capital expenditure and hence allowing their cash reserves to accumulate, or optimizing firms cutting back on capital expenditure and hence choosing to hold higher levels of cash due to their lower levels of collateral and higher borrowing constraints

This overall 2.5 percent increase in average target cash-to-asset ratios occurs despite an improving demand outlook which contributes to lower target cash-to-asset ratios. The 
positive contributions of cash flow, cash flow uncertainty and capital expenditure more than offset the negative contribution from the improving demand outlook. ${ }^{20}$

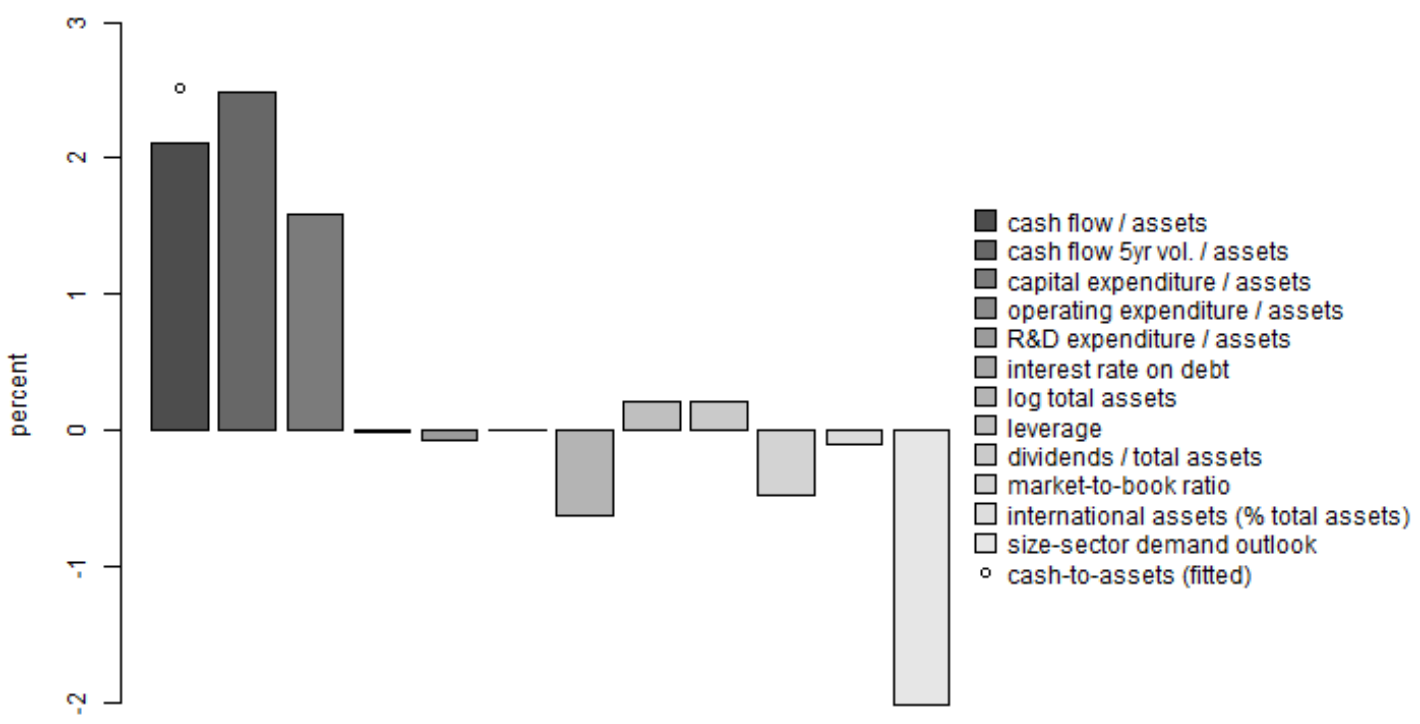

Figure 6. Average across firms of the change in implied target cash-to-asset ratios $\hat{y}_{i t}^{*}$ from the baseline regression in specification (2) of Table 1 between 1999 and 2011. The average change in baseline target cash-to-asset ratio is decomposed into the average change in the explanatory variables multiplied by their respective coefficients. The contributions from time fixed effects are small and have been surpressed in this plot to save space.

Figure 5 shows that the transaction cost and precautionary demand theories can explain much of the variation over time in the allocations of firm assets to cash. These theories can also explain the allocation of firm assets to cash across firms at a point in time. Figures 7-9 show that the excess cash assets held in Japanese nonfinancial firms in 2013 are concentrated in smaller firms, in the tradable sector and among exporters. Smaller firms tend to hold a higher share of their assets in cash because they are more financing constrained than larger firms, but given the government's expansionary monetary policy it is hard to believe that financing constraints worsened between 2011 and 2013. The more compelling explanation is that smaller firms have unintentionally let their cash holdings accumulate over this period.

Similarly, exporters of tradable goods experienced high profits between 2011 and 2013 due to a depreciating yen. Since I control for these profits through operating cash flows in the baseline specification, it must be the case that these exporters of tradable goods saved a higher share of their cash inflows than they did before 2011. This increase in the rate of

\footnotetext{
${ }^{20}$ Note that target cash-to-asset ratios do not depend on the lagged dependent variable, even though actual and fitted cash-to-asset ratios depend on the lagged dependent variable. Hence there is no contribution from the lagged dependent variable in Figure 6.
} 
saving could have been intentional or unintentional. Almeida et al. (2004) argue that a firm's financing constraints determine the extent to which it saves cash out of cash flow. Again given the expansionary monetary policy over the period, it is hard to argue that financing constraints have risen between 2011 and 2013. The more compelling explanation therefore is that exporters of tradable goods have unintentionally let the increased profits from a depreciating yen add more to their share of assets allocated to cash than they would have allowed in previous years.
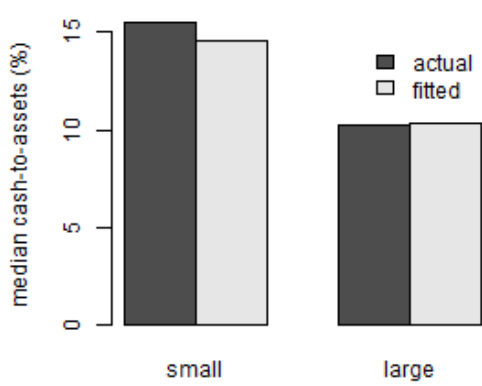

Figure 7. Median across firms of the actual and baseline fitted cash-to-asset ratios by firm size in 2013.

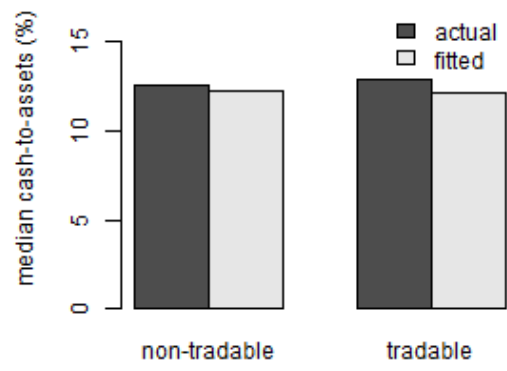

Figure 8. Median across firms of the actual and baseline fitted cash-to-asset ratios by firm sector in 2013.

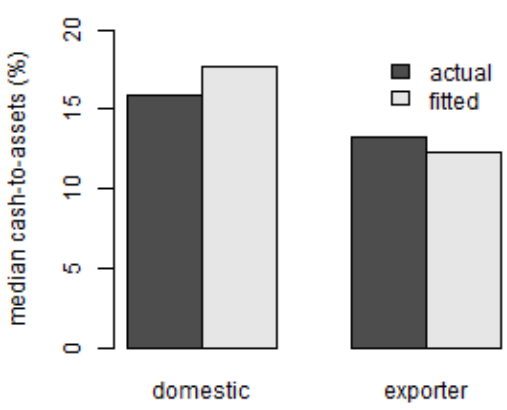

Figure 9. Median across firms of the actual and baseline fitted cash-to-asset ratios by degree of a firm's foreign activity in 2013.

\section{Consequences of High and Rising Cash Holdings in Japan}

Figure 1 above suggests that Japanese nonfinancial firms' accumulation of cash in the last decade has been at the expense of investment. In this section I show that this interpretation also holds at the firm level after controlling for other factors thought to determine firm-level investment. ${ }^{21}$ I estimate a standard model for firm-level investment following Syed and Lee (2010) and Kang (2014) that explains investment in terms of:

- Tobin's Q, measured by the market value of equity divided by the book value of equity, as a forward-looking indicator of investment opportunities

- Liquidity, measured by the firm's operating cash flow divided by total assets, which should be more important for investment if the firm is more financing constrained

\footnotetext{
${ }^{21}$ The negative coefficient in the regression of cash-to-asset ratios on investment in the baseline system GMM specification in Table 1 above reflect (i) the contemporaneous covariance between cash-to-asset ratios and investment, (ii) the longitudinal autocovariance in investment due the instrument set, and (iii) the set of control variables in the regression. The same coefficient in the fixed effects regression reflects only (i) and (iii). Therefore, we cannot say that we have found evidence for the trade-off between cash holdings and investment based on the regressions in Table 1 alone.
} 
- Leverage, measured by the ratio of the book value of assets to the book value of equity, to capture the effect of the firm's debt burden on its investment behavior

- Uncertainty, measured by the average across firms within each sector (defined by first digit ICB code) of the 5-year rolling standard deviation of returns on assets, to capture the option value of delaying investment at times of high uncertainty.

I add the firm's cash holdings as a share of total assets as an additional explanatory variable to test whether there is a trade-off between investment and cash holdings after controlling for other factors thought to affect the firm's investment decision. I also add a lagged dependent variable to allow for persistency in capital expenditure that could arise, for example, through adjustment costs.

Table 3 reports the estimation results using fixed effects (1) and using system GMM with a lagged dependent variable (2). The coefficients of the estimation results under fixed effects and system GMM agree with each other in signs and in approximate magnitude, and they agree with predictions from theory. The Hansen test is rejected for the system GMM specification, suggesting that focusing on the fixed effects estimation results is preferable. The coefficient on cash holdings is statistically significant and negative, providing evidence for the trade-off between Japanese nonfinancial firms' investment spending and their cash stocks. In particular, the fixed effects estimation suggests that a 1 percentage point increase in the ratio of a firm's cash to total assets could reduce its capital expenditure by 0.06 percent of total assets. Policies to release some of these cash stocks could therefore result in higher investment.

Table 3. Fixed effect (1) and system GMM (2) estimation results for the ratio of capital expenditures to total assets in a firm--year panel of Japanese nonfinancial firms. Standard errors in parentheses are heteroskedasticity-robust in (1) and Windmeijer-corrected in (2). Two-way firm and year fixed effects are included in all models. In each estimation, the reported $R^{2}$ is calculated as the squared correlation between actual and fitted values of the dependent variable. 


\begin{tabular}{|c|c|c|}
\hline & $\begin{array}{c}\text { (1) } \\
\text { capital exp. / } \\
\text { assets ( percent) }\end{array}$ & $\begin{array}{c}\text { (2) } \\
\text { capital exp. / } \\
\text { assets ( percent) }\end{array}$ \\
\hline \multirow[t]{2}{*}{ capital exp. / assets = L, } & & $0.0860 * *$ \\
\hline & & $(0.0414)$ \\
\hline \multirow[t]{2}{*}{ market-to-book ratio } & 0.0167 & $0.143 * * *$ \\
\hline & $(0.0388)$ & $(0.0478)$ \\
\hline \multirow[t]{2}{*}{ cash flow from operations / assets } & $28.09 * * *$ & $30.27 * * *$ \\
\hline & $(5.925)$ & (5.987) \\
\hline \multirow[t]{2}{*}{ leverage } & -0.00115 & $-0.0146 * * *$ \\
\hline & $(0.00427)$ & $(0.00507)$ \\
\hline \multirow[t]{2}{*}{ sector ROA 5-yr vol. } & -0.0207 & $-0.0468 * *$ \\
\hline & $(0.0196)$ & $(0.0233)$ \\
\hline \multirow[t]{2}{*}{ cash-to-assets ( percent) } & $-0.0623 * * *$ & $-0.0552 * * *$ \\
\hline & $(0.00802)$ & $(0.0185)$ \\
\hline Observations & 22,331 & 23,844 \\
\hline Number of firms & 2,121 & 3,400 \\
\hline$R^{2}$ & 0.655 & 0.278 \\
\hline Number of instruments & & 803 \\
\hline Hansen test $p$-value & & $<0.01$ \\
\hline
\end{tabular}

It is a stylized fact that Japanese firms pay lower dividends out of profits than firms in G7 peer countries. In addition, in Figures 3 and 4 below I show that aggregate dividends of Tokyo Stock Exchange $1{ }^{\text {st }}$ Section firms are less sensitive to their aggregate profits than aggregate dividends of S\&P 500 firms are to their aggregate profits. One might therefore expect dividend growth to respond to the recent two decades of profit growth more sluggishly in Japan than in the US, while nonfinancial firm cash holdings were accumulating.

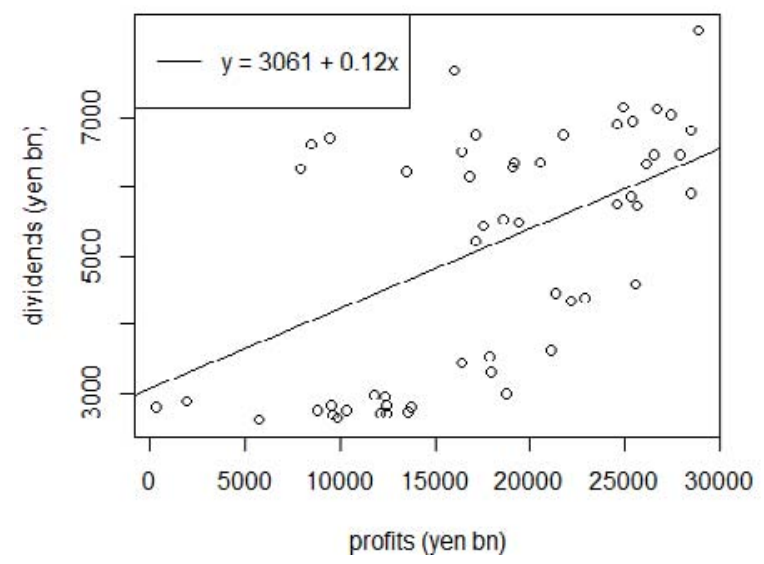

Figure 10. Tokyo Stock Exchange $1^{\text {st }}$ Section, 2009Q3 - 2014Q2. Source: Haver

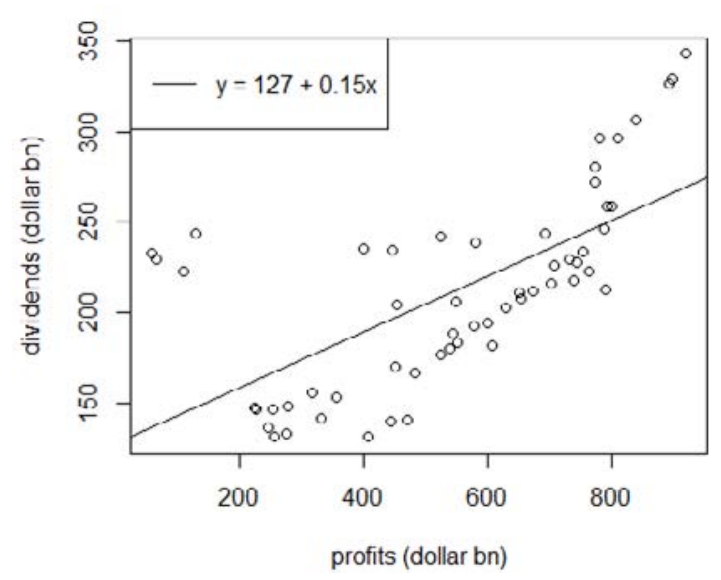

Figure 11. S\&P500, 2009Q3-2014Q2.

Source: Haver 
I investigate the firm-level evidence for a trade-off between paying dividends and accumulating cash. Following Denis and Osobov (2008) I construct the following explanatory variables that theory predicts should explain dividend payout ratios:

- $\quad$ Firm size, measured as the natural logarithm of total assets in yen. Larger firms are less financing constrained and hence have less reason to retain profits for financing projects later.

- $\quad$ Tobin's Q, measured as the ratio of the market value of equity to the book value of equity is again a forward-looking indicator of investment opportunities. The greater the firm's investment opportunities, the less the firm could be expected to pay in dividends.

- The proportion of retained earnings in book equity. To the extent that dividend payout ratios reflect the firm's desire to smooth its free cash flow over time, the age of the firm is the most important determinant of its free cash flow (Allen and Michaely, 2003; DeAngelo, DeAngelo and Skinner, 2004; DeAngelo and DeAngelo, 2006). In the early part of the firm's life cycle, it has ample investment opportunities and limited free cash, so it pays out less of its profits as dividends. In the later part of the firm's life cycle, the firm has fewer investment opportunities and more free cash flow. The proportion of retained earnings in book equity is a measure of the maturity of the firm.

- Return on assets, measured as the ratio of net profit after tax to total assets. To the extent that dividend payout ratios are a device for conveying information about firm profitability to investors, higher returns on assets should be associated with higher dividend declarations.

In addition I introduce three further explanatory variables. The first directly measures cash flow, rather than approximating it through the ratio of retained earnings to common equity.

- The ratio of cash flow to total assets. If the firm seeks to use its dividend policy to smooth cash flows over time, its dividend payout ratios should be positively associated with operating cash flows.

- The ratio of the 5-year rolling standard deviation of firm cash flow to total assets. We would expect more uncertainty around the firm's future liquidity position to result in lower dividends

- The ratio of capital expenditure to total assets. We would expect that more capital expenditure leaves less cash available to pay dividends and hence lower dividend declarations. 
I present the results of the tobit estimation for dividend payout ratios in column (1) of Table 4, and I present the estimation results of the fixed effect and system GMM linear probability models in columns (2) to (3) of that table. From specification (1), the size of the firm's cash stock is a statistically significant negative predictor of the magnitude of its dividends in normal times, even after controlling for other factors thought to determine the dividend declaration decision. However, from specifications (2) and (3) there is no evidence that the size of the firm's cash holdings affects its decision of whether or not to declare dividends. The trade-off between cash holdings and dividend declarations therefore exists on the intensive but not the extensive margin.

Table 4. Estimation results for (1) a tobit regression of the dividend payout ratio censored between 0 and 100 percent, (2) a fixed effect linear probability model for whether or not dividends are declared in a firm-year and (3) a system GMM linear probability model for whether or not dividends are declared in a firm - year. Two-way firm and year fixed effects are included in specifications (2) and (3), while year- and industry-specific fixed effects are included in (1) due to problems of consistent estimation in fixed effect tobit models. Standard errors in parentheses are clustered at the firm level in specifications (1) and (2), and they include a Windmeijer correction in (3). Coefficients or standard errors of zero are only zero to two decimal places; such coefficients are not economically significant. In each estimation, the reported $R^{2}$ is calculated as the squared correlation between actual and fitted values of the dependent variable. 


\begin{tabular}{|c|c|c|c|}
\hline & $\begin{array}{c}\text { (1) } \\
\text { dividend } \\
\text { payout } \\
\text { ratio } \\
\text { ( percent) }\end{array}$ & $\begin{array}{c}\text { (2) } \\
\text { dividends } \\
\text { indicator }\end{array}$ & $\begin{array}{c}\text { (3) } \\
\text { dividends } \\
\text { indicator }\end{array}$ \\
\hline total assets (log) & $\begin{array}{c}1.45^{* * *} \\
(0.29)\end{array}$ & $\begin{array}{c}0.05^{* * *} \\
(0.01)\end{array}$ & $\begin{array}{c}0.05^{* * *} \\
(0.01)\end{array}$ \\
\hline market-to-book ratio & $\begin{array}{l}-0.21 \\
(0.18)\end{array}$ & $\begin{array}{l}-0.00 \\
(0.00)\end{array}$ & $\begin{array}{c}-0.01^{* * *} \\
(0.00)\end{array}$ \\
\hline return on assets ( percent) & $\begin{array}{c}1.31^{* * *} \\
(0.19)\end{array}$ & $\begin{array}{c}0.02^{* * *} \\
(0.01)\end{array}$ & $\begin{array}{c}0.01 * * * \\
(0.00)\end{array}$ \\
\hline retained earnings / book equity & $\begin{array}{l}0.66^{*} \\
(0.38)\end{array}$ & $\begin{array}{l}-0.00 \\
(0.00)\end{array}$ & $\begin{array}{c}-0.00 * * * \\
(0.00)\end{array}$ \\
\hline $\begin{array}{l}\text { cash flow from operations / } \\
\text { assets }\end{array}$ & $\begin{array}{l}11.00 \\
(9.10)\end{array}$ & $\begin{array}{c}0.28 \\
(0.22)\end{array}$ & $\begin{array}{c}0.43 \\
(0.27)\end{array}$ \\
\hline $\begin{array}{l}\text { firm cash flow } 5 \text {-yr vol. } \\
\text { ( percent assets) }\end{array}$ & $\begin{array}{l}-0.34^{*} \\
(0.18)\end{array}$ & $\begin{array}{c}0.00 \\
(0.00)\end{array}$ & $\begin{array}{c}0.00 \\
(0.00)\end{array}$ \\
\hline cash-to-assets ( percent) & $\begin{array}{c}-0.15^{* * *} \\
(0.04)\end{array}$ & $\begin{array}{l}-0.00 \\
(0.00)\end{array}$ & $\begin{array}{l}0.00^{* *} \\
(0.00)\end{array}$ \\
\hline Observations & 25,671 & 25,671 & 25,671 \\
\hline Number left-censored & 6037 & & \\
\hline Number right-censored & 1573 & & \\
\hline Number uncensored & 18061 & & \\
\hline Number of firms & 3,720 & 3,720 & 3,720 \\
\hline$R^{2}$ & & 0.527 & 0.166 \\
\hline Number of instruments & & & 1082 \\
\hline Hansen test $p$-value & & & 0.00 \\
\hline
\end{tabular}

\section{Conclusion And Policy Discussion}

Cash holdings of nonfinancial firms are large and rising in many countries. In some cases like Japan and the US, nonfinancial firms are becoming net lenders to other sectors in the economy. In this paper I show that transaction cost and precautionary demand theories, which have been found to explain cash holdings in other countries, also explain much of the variation in cash holdings in Japan, including their accumulation since 2000.

In doing so, I test for the influence of three additional variables in explaining cash holdings: (i) the lagged dependent variable to capture persistence in cash brought about by the adjustment costs that would be incurred in rebalancing cash holdings year-to-year, (ii) industry-level expectations of future demand that affect the extent to which cash has an 
inherent time or option value, and (iii) firm-level risk aversion which affects the extent to which management might self-insure against cash shortfalls. I find strong evidence for the importance of the lagged dependent variable and the demand outlook in explaining cash holdings, and only limited evidence for the role of risk aversion, in addition to existing variables in the literature. Despite the difficulties associated with measuring corporate governance, I find limited support for the agency theory explanation of cash holdings insofar as firms whose CEO acts as chairman of the board of directors hold 1.04 percent more of their assets in cash than other firms, holding other motivations constant.

The baseline model, which explains about 80 percent of the variation Japanese nonfinancial firm cash holdings based on the transaction cost and precautionary demand theories, predicts that the median firm should have reduced its cash holdings between 2011 and 2013, primarily due to an improving demand outlook. Instead, the median firm increased its cash holdings over this period, to hold 'excess' cash of about 2.5 percent of total assets, or 5 percent of GDP in 2013. ${ }^{22}$ Although it is difficult to distinguish whether firms unintentionally or intentionally accumulate cash in responding to their changing circumstances, the government's recent expansionary monetary policies make it difficult to believe that the median firm has intentionally accumulated cash because it has become more financing constrained over this period. Instead, a more compelling explanation for the recent sharp rise in cash-to-asset ratios seems to be that firms have unintentionally let their cash balances accumulate during a time of high profitability.

I also find strong evidence that the accumulation of cash balances in Japanese nonfinancial firms takes place to the detriment of firm investment and dividend declarations. This finding suggests that policies to encourage firms to invest some of their unnecessary cash could boost investment directly and consumption indirectly through dividends.

The Japanese government is currently pursuing policies to strengthen corporate audit and monitoring functions, to encourage companies to nominate independent outside directors and to increase the fiduciary responsibilities of institutional investors (Aoyagi and Ganelli, 2014). Weighted against the above empirical evidence, these policies can be expected to have limited short term effectiveness in reducing cash holdings, although in the longer term they could attract more foreign direct investment into Japan and reduce the cost to managers of raising external finance, which would alleviate some of the distortions associated with Japan's powerful banking sector. However, I do find evidence that each percentage point reduction in the proportion of firms with dual CEOs could release cash holdings of 1 percent of nonfinancial firm assets, which translates into about 2 percent of GDP. In 2013, 78 percent of Japanese nonfinancial firms had dual CEOs, compared to about 60 percent of S\&P 500 firms (Krause, 2013). Therefore, policies aimed at bringing rates of CEO duality in Japanese nonfinancial firms into line with international norms could materially reduce cash holdings.

\footnotetext{
${ }^{22}$ According to the national accounts published by the Bank of Japan, Japanese nonfinancial firm assets amounted to 2.07 times nominal GDP in 2013.
} 
The Korean government recently announced a policy of taxing by 10 percent the net profits of the largest 1 percent of domestic companies by market capitalization if these companies fail to pay between 60 percent and 80 percent of their revenues out as investment, wage increases or shareholder dividends. This policy penalizes a few firms with the greatest resources for accumulating more cash than they currently hold. However, cash holdings are much lower relative to assets and debt in Korea than in Japan, and their growth has been much more limited. The advantages of the Korean tax are that it can be implemented quickly, its compliance can be easily monitored and enforced, and it generates revenue that could be used to reduce the government's debt burden. The disadvantages of the tax are that it can incentivize the firms it targets to invest in value-destroying projects, it incentivizes the firms it does not target to accumulate more cash as self-insurance against future policy action against them, and it is conceptually easy to avoid by manipulating the timing and classification of revenues and costs on the income statement.

Other policies could be aimed at reducing distortions that could be driving the accumulation in cash or could be holding back investment. For example, the persistence of cash holdings year-to-year, the propensity to save cash out of cash flow and the positive effect of cash flow volatility on cash holdings all suggest that there are many Japanese nonfinancial firms that are financing constrained. Given the fixed costs associated with raising external finance, small firms are thought to be the most financing constrained. Assisting small enterprises to obtain non-bank finance could be the most effective way to bring down average cash-to-asset ratios in Japan.

Policies that reduce the uncertainty in operating cash flows could be expected to lead to a sizable reduction in Japanese nonfinancial firm cash-to-asset ratios. Price stability should be a key mechanism for reducing this operating cash flow uncertainty, although steady low interest rates do not seem to encourage the employment of cash reserves. I also find slight evidence that reducing the level of risk aversion in Japanese nonfinancial firms could help to lower cash-to-asset ratios. The current government's policies to challenge the corporate psychology of caution are a step in the right direction. Similarly, policies that continue to improve the domestic demand outlook would continue to fight the accumulation of cash holdings among these firms. 


\section{References}

Acharya, V. V., Almeida, H., and M. Campello, 2007, Is cash negative debt? A hedging perspective on corporate financial policies. Journal of Financial Intermediation. $16(4), 515-54$.

Allen, F., Michaely, R., 2003, Dividend policy. In: Constantinides, G., Harris, M., Stulz, R. (Eds.), Handbook of the Economics of Finance. North-Holland, Amsterdam.

Almeida, H., Campello, M. and M.S. Weisbach, 2004, The Cash Flow Sensitivity of Cash. The Journal of Finance. 59(4) pp. 1777-1804.

Aoyagi, C. and G. Ganelli, 2014, Unstash the Cash! Corporate Governance Reform in Japan. IMF Working Paper No. 14/140, pp. 1-23.

Bates, T., Kahle, K. and R. Stulz. 2009, Why Do US Firms Hold So Much More Cash than They Used To? The Journal of Finance. 64(5) pp. 1985-2021.

DeAngelo, H., DeAngelo, L., 2006, The irrelevance of the MM dividend irrelevance theorem. Journal of Financial Economics 79. pp. 293-316.

DeAngelo, H., DeAngelo, L., Skinner, D.J., 2004, Are dividends disappearing? Dividend concentration and the consolidation of earnings. Journal of Financial Economics. 72, pp. 425-456.

Denis, D. J. and I. Osobov. 2008, Why do firms pay dividends? International evidence on the determinants of dividend policy. Journal of Financial Economics. 89(1), 62-82.

Dittmar, A., Mahrt-Smith, J., and H. Servaes. 2003, International Corporate Governance and Corporate Cash Holdings. Journal of Financial and Quantitative Analysis. 38(1) pp. $111-33$.

Han, S. and J. Qiu. 2007, Corporate precautionary cash holdings. Journal of Corporate Finance. 13: 43-57.

Hori, K., Koichi, A. and M. Saito. 2010, On the Determinants of Corporate Cash Holdings in Japan: Evidence from Panel Analysis of Listed Companies (Japanese). Gendai Finance. 27: 3-24.

Hoshi, K., Kashyap, A., and D. Shrafstein. 1991, Corporate Structure, Liquidity and Investment: Evidence from Japanese Industrial Groups. Quarterly Journal of Economics. 106(1): 33-60.

International Monetary Fund, 2014, Japan Article IV Consultation. IMF Country Report No. 14/236. Washington, DC 
Ivanova, A. and F. Raei, 2014, Corporate Cash Holdings: Is Germany Different? IMF Working Paper (forthcoming).

Jensen, M. 1986, Agency Cost for Free Cash Flow, Corporate Finance, and Takeovers. American Economic Review. 57(2), pp. 283-306.

Kang, J.S., 2014, Balance Sheet Repair and Corporate Investment in Japan. IMF Working Paper No. 14/141, pp. 1-21.

Keynes J.M. 1936, The General Theory of Employment, Interest and Money. Harcourt Brace: London.

Krause, R., Semadeni, M. and A.A. Cannella, Jr. CEO Duality: A Review and Research Agenda. Journal of Management. 40(1): 256-86.

Miller M. and D. Orr. 1966, A Model of the Demand for Money by Firms. Quarterly Journal of Economics. 80, pp. 413-35.

Mulligan, C. 1997, Scale Economies, the Value of Time, and the Demand for Money: Longitudinal Evidence from Firms. Journal of Political Economy. 105, pp. 1061-79.

Myers, S. and N. Majluf. 1984, Corporate Financing and Investing Decisions When Firms Have Information That Investors Do Not Have. Journal of Financial Economics. 13(2), pp. 187-221.

Naoki, S. 2012, Firms' Cash Holdings and Performance: Evidence from Japanese Corporate Finance. RIETI Discussion Paper Series. Development Bank of Japan. 12-E-031.

Opler, T., Pinkowitz, L., Stulz, R. and R. Williamson. 1999, The Determinants and Implications of Corporate Cash Holdings. Journal of Financial Economics. 52, pp. 346.

Pinkowitz, L. and R. Williamson. 2001, Bank Power and Cash Holdings: Evidence from Japan. Review of Financial Studies. 14, pp. 1059-82.

Rajan, R. and L. Zingales. 1995, What Do We Know about Capital Structure? Evidence from International Data. Journal of Finance. 50, pp. 1421-60.

Syed, M. and J. Lee. 2010, Japan's Quest for Growth: Exploring the Role of Capital and Innovation. IMF Working Paper No. 10/294, pp. 1-20.

Wooldridge, J., 2010, Econometric Analysis of Cross Section and Panel Data. Cambridge: MIT Press. 